\title{
The Role of Spirituality in Patients Undergoing Hematopoietic Stem Cell Transplantation: a Systematic Mixed Studies Review
}

\author{
Li-yuan Zheng, BS, RN ${ }^{7}$, Hua Yuan, $P h D^{2}$, Zi-jun Zhou, $\mathrm{MM}^{3}$, Bao-xing Guan, BS, $R N^{4}$, \\ Ping Zhang, $P h D^{5}$, and Xiu-ying Zhang, $P h D^{7}$ (D)
}

'Department of Fundamental Nursing, School of Nursing , Jilin University, Changchun, Jilin, People's Republic of China; ${ }^{2}$ Department of Surgical Nursing, School of Nursing, Jilin University, Changchun, Jilin, People's Republic of China; ${ }^{3}$ Jilin Cancer Hospital, Changchun, Jilin, People's Republic of China; ${ }^{4}$ Intensive Care Unit, First Hospital of Jilin University, Changchun, Jilin, People's Republic of China; ${ }^{5}$ School of Nursing, Southern Medical University, Guangzhou, Guangdong, People's Republic of China.

\begin{abstract}
BACKGROUND: Hematopoietic stem cell transplantation (HSCT) has become the standard treatment for many diseases, but it is an intense and distinctive experience for patients. HSCT-related mortality is present throughout the whole process of transplantation, from pretransplantation to recovery. Long-term rehabilitation and the uncertain risk of death evoke feelings of vulnerability, helplessness, and intense fear. Zimmermann et al. proposed that spiritual well-being is an important dimension of quality of life and that patients at the end stage of life require spiritual support in addition to physical care, psychological care, and social support. Therefore, the purpose of this review is to examine the role of spirituality in the process of HSCT.
\end{abstract}

METHOD: A systematic mixed studies review (SMSR) was based on Pluye and Hong's framework to understand the role of spirituality in patients' experiences while undergoing HSCT. We use the preferred reporting items for systematic reviews and meta-analyses (PRISMA) statement to report the results of integration.

RESULTS: Fifteen original qualitative studies, 19 quantitative studies, and one mixed method study were included in the systematic mixed studies review. The evidence from the review revealed the following three themes: the spiritual experiences of HSCT patients, the spiritual coping styles of HSCT patients, and the spiritual need changes brought about by HSCT.

DISCUSSION: Few medical institutions currently offer spiritual healing, although HSCT patients with different cultural backgrounds may have different spiritual experiences and spiritual coping styles. Psychotherapists or nurses should be considered to provide spiritual care for patients undergoing HSCT, to help patients cope with disease pressures, promote HSCT patients' comfort, and improve their quality of life.

KEY WORDS: hematopoietic stem cell transplantation; spirituality; systematic mixed studies review; quality of life.

$\mathrm{J}$ Gen Intern Med 35(7):2146-61

DOI: $10.1007 / \mathrm{s} 11606-020-05741-1$

(c) Society of General Internal Medicine 2020

Received November 14, 2019

Accepted February 11, 2020

Published online February 24, 2020

\section{INTRODUCTION}

Hematopoietic stem cell transplantation (HSCT) has become the standard treatment for many diseases and offers the hope of a cure, but it is a distinctive experience for patients. ${ }^{1,2}$ HSCTrelated mortality is present throughout the whole process of transplantation, from pretransplantation to recovery, including the risks related to pretransplant infection, bleeding, graftversus-host disease, infection, relapse, and gastrointestinal complications because of immune function complexity. Long-term rehabilitation and the uncertain risk of death evoke feelings of vulnerability, helplessness, and intense fear. ${ }^{2,3}$ Prior literature has reported that patients have different coping styles when facing life-threatening diseases. ${ }^{4,5}$ A negative coping style can deteriorate the quality of life and the prognosis of patients, ${ }^{6}$ while a positive coping style can relieve the psychological pressure of patients. ${ }^{1}$

Spirituality originates from religion and can be defined as "experiencing a meaningful connection to our core selves, others, the world, and/or a greater power, as expressed through our reflections, narratives, and actions"; ${ }^{7}$ thus, spirituality does not always contain notions of a formal religion. ${ }^{8}$ Spirituality is a major component for patients with life-threatening diseases as it provides them with comfort, personal growth, and meaning in life. ${ }^{9}$ Several studies have proven that spirituality and beliefs play significant roles in patients' positive coping styles in the face of cancer diagnosis and treatment 10,11 and indicate better health outcomes, such as allowing patients to better adjust to their illness and better experience the meaning of life. ${ }^{12,13}$

At present, qualitative studies of HSCT mainly focus on the survival experience before, during, and after HSCT. Studies on the spiritual experiences of patients with HSCT are rare. Spiritual experiences often promote positive health outcomes as a dimension of quality of life or as an aspect of supportive care, but it is not clear what role spiritual support plays in HSCT patients. There are some limitations in single qualitative research regarding the guidance of clinical practice. Therefore, 
we aim to integrate qualitative and quantitative research evidence on the spiritual experiences of HSCT patients to understand the spiritual experiences and needs of HSCT patients more comprehensively and promote people-oriented nursing clinical practices.

\section{METHODS}

Based on Pluye and Hong's ${ }^{14}$ framework, a systematic mixed studies review (SMSR) was conducted to evaluate and integrate evidence on the spirituality of patients undergoing HSCT and to describe the role of spirituality in the experience of HSCT patients. This review integrated qualitative, quantitative, and mixed research methods to ensure a comprehensive understanding of the phenomenon. ${ }^{14}$ The application of the seven steps of the mixed studies review guidelines ensured the rigor of the review. ${ }^{14}$ In addition, we used the preferred reporting items for systematic reviews and meta-analysis (PRISMA) statement ${ }^{15}$ to report the results of integration.

\section{Stage 1: Formulate a Review Question}

What role does spirituality play in the experiences of patients undergoing HSCT?

\section{Stage 2: Define the Eligibility Criteria}

Published qualitative, quantitative, and mixed methods studies were included to gain a comprehensive understanding of HSCT patients' spirituality. The inclusion criteria were as follows:

(i) Research type: Qualitative research, quantitative research, and mixed methods studies.

(ii) Sample: Individuals who express spirituality before or after undergoing HSCT.

(iii) Research content: Articles were included if they mentioned or referred to any of the selected spiritual experiences, viewpoints, domains quality of life, or needs in the process of HSCT.

\section{Stage 3: Apply an Extensive Search Strategy}

The main search terms are as follows: spirituality, spiritualism, spiritual therapies, spiritual healing, exorcism, survivorship, hematopoietic stem cell transplantation, and bone marrow transplantation. See Table 1 for the specific search strategy.

4. Stages 4 and 5: Identify and Select Relevant Studies

Searches were conducted in the PubMed, Web of Science, Embase, CINAHL, and Cochrane Library databases (from date of record to 2019 February 23). Two reviewers (first author and last author) independently screened the abstracts of the articles identified by the search strategy. The two reviewers discussed and reached a consensus on the papers that should be included. The process of literature identification is shown in Figure 1.

5. Stage 6: Appraise the Quality of the Included Studies

Critical appraisal was conducted in collaboration between the first author (L.Y.Z.) and the last author (X.Y.Z.) by using the Mixed Methods Appraisal Tool (MMAT) (Version 2018). All of the articles were significant in relation to the spiritual domain, and none were excluded in the quality appraisal process. Please see Table 2 for MMAT scoring; a star represents an affirmative answer to a question.

\section{Stage 7: Synthesize Included Studies}

The thematic synthesis framework developed by Thomas and Harden ${ }^{16}$ was conducted in three stages (re-reading and understanding the results or the findings section of each article, identifying similar concepts across studies, and identifying themes). Specifically, the main authors immersed themselves in the data by reading and re-reading the results or the findings section of each article, identifying simple concepts across the articles, and producing a synthesis that is close to the findings of the included articles. New themes emerged and changed through discussion by the authors. In our study, two main researchers (L.Y.Z. and X.Y.Z.) from our research group repeatedly read the backgrounds, methods, results, and discussions of the original research to understand the results of the original research as much as possible. To reduce the risk of data bias, the two authors summarized similar topics and identified a more appropriate topic through discussion when they had differences.

\section{RESULTS}

\section{Included Studies}

A total of 652 records were identified, and after deduplication, 35 articles were included in this review (please see the PRISMA flow diagram in Fig. 1). These 15 qualitative studies, 19 quantitative studies, and one mixed method study were published between 1997 and 2018. The quantitative studies include quantitative descriptive studies and nonrandomized psychoeducational support intervention studies. The qualitative studies include grounded theory studies, descriptive or hermeneutic phenomenological studies, qualitative descriptive studies, thematic or content analyses, and case analyses. The mixed research method consisted of a convergent design. Please see Table 2 for the characteristics of the studies and Table 3 for the characteristics of the participants.

\section{Critical Appraisal}

There are differences in the methodological quality of the studies. All of the articles were significant in relation to the spiritual domain, and none were excluded in the quality 
Table 1 Search Strategy to Identify Articles About HSCT Spirituality (Search Date: from Record to 2019 February 23)

\begin{tabular}{|c|c|c|c|}
\hline $\begin{array}{l}\text { Literature } \\
\text { database }\end{array}$ & Hematopoietic stem cell transplantation & Spiritual need related topics & $\begin{array}{l}\text { Total } \\
\text { articles } \\
\text { identified }\end{array}$ \\
\hline PubMed & $\begin{array}{l}\text { \#1 (“Bone Marrow Transplantation”[Mesh]) OR } \\
\text { (((((Grafting, Bone Marrow[Title/Abstract]) OR Bone } \\
\text { Marrow Grafting[Title/Abstract]) OR Transplantation, } \\
\text { Bone Marrow[Title/Abstract]) OR Bone Marrow Cell } \\
\text { Transplantation[Title/Abstract]) OR Transplantation, } \\
\text { Bone Marrow Cell[Title/Abstract]) } \\
\text { \#2 (((Stem Cell Transplantation, } \\
\text { Hematopoietic[Title/Abstract]) OR Transplantation, } \\
\text { Hematopoietic Stem Cell[Title/Abstract])) OR } \\
\text { "Hematopoietic Stem Cell Transplantation”[Mesh] } \\
\text { \#3 \#1OR\#2 }\end{array}$ & $\begin{array}{l}\text { \#4 (“Spirituality”[Mesh]) OR spiritualities } \\
\text { [Title/Abstract] } \\
\text { \#5 ((((((((Therapies, Spiritual[Title/Abstract]) OR } \\
\text { Spiritual Healing[Title/Abstract]) OR Healing, } \\
\text { Spiritual[Title/Abstract]) OR Healings, } \\
\text { Spiritual[Title/Abstract]) OR Spiritual } \\
\text { Healings[Title/Abstract]) OR Exorcism[Title/Abstract]) } \\
\text { OR Exorcisms[Title/Abstract])) OR “Spiritual } \\
\text { Therapies”[Mesh] } \\
\text { \#6 “Survivorship”[Mesh] } \\
\text { \#7 \#4AND\#5AND\#6 }\end{array}$ & $\begin{array}{l}\text { \#3 AND } \\
\# 7-74\end{array}$ \\
\hline CINAHL & $\begin{array}{l}\mathrm{S} 1=\mathrm{SU} \text { (hematopoietic stem cell transplantation or bone } \\
\text { marrow transplant) OR TI (hematopoietic stem cell } \\
\text { transplantation or bone marrow transplant) }\end{array}$ & $\begin{array}{l}\text { S2 SU Survivorship OR TI Survivorship } \\
\text { S3 SU Exorcism OR TI Exorcism } \\
\text { S4 SU Spiritual Therapies OR TI Spiritual Therapies } \\
\text { S5 SU Spiritual Healing OR TI Spiritual Healing } \\
\text { S6 SU Spirituality OR TI Spirituality } \\
\text { S7=S2 OR S3 OR S4 OR S5 OR S6 }\end{array}$ & $\begin{array}{l}\text { S1 AND } \\
\text { S7-23 }\end{array}$ \\
\hline Web of & \#1 TOPIC: ("bone marrow transplantation") OR TOPIC: & \#4 TOPIC: (Spirituality) OR TOPIC: (Spiritualities) & \#3 AND \\
\hline Science & $\begin{array}{l}\text { ("Grafting, Bone Marrow") OR TOPIC: ("bone marrow } \\
\text { grafting") OR TOPIC: ("transplantation, bone marrow") } \\
\text { OR TOPIC: ("bone marrow cell transplantation") OR } \\
\text { TOPIC: ("transplantation, bone marrow cell") } \\
\text { \#2 TOPIC: ("Hematopoietic Stem Cell Transplantation") } \\
\text { OR TOPIC: ("Stem Cell Transplantation, Hematopoietic") } \\
\text { OR TOPIC: ("Transplantation, Hematopoietic Stem Cell") } \\
\text { \#3 \#1 OR \#2 }\end{array}$ & $\begin{array}{l}\text { OR TOPIC: ("spiritual therapy") OR TOPIC: } \\
\text { ("spiritual healing") OR TOPIC: (exorcism) OR } \\
\text { TOPIC: (survivorship) OR TOPIC: (religion) }\end{array}$ & $\# 4-288$ \\
\hline Embase & $\begin{array}{l}\text { \#1 'bone marrow transplantation'/exp. } \\
\text { \#2 'bone marrow transplantation':ab,ti OR 'grafting, } \\
\text { bone marrow':ab,ti OR 'bone marrow grafting':ab,ti OR } \\
\text { 'transplantation, bone marrow':ab,ti OR 'bone marrow cell } \\
\text { transplantation':ab,ti OR 'transplantation, bone marrow } \\
\text { cell':ab,ti } \\
\text { \#3 'hematopoietic stem cell transplantation'/exp. } \\
\text { \#4 'hematopoietic stem cell transplantation':ab, } \\
\text { ti OR 'stem cell transplantation, hematopoietic':ab, } \\
\text { ti OR 'transplantation, hematopoietic stem cell':ab, ti } \\
\text { \#5 \#1 OR \#2 } \\
\text { \#6 \#3 OR \#4 } \\
\text { \#7 \#5 OR \#6 }\end{array}$ & $\begin{array}{l}\text { \#8 'religion':ab,ti OR 'spirituality':ab,ti OR } \\
\text { ‘spiritualities':ab,ti OR ‘spiritual therapies':ab,ti OR } \\
\text { ‘spiritual healing':ab,ti OR ‘exorcism':ab,ti OR } \\
\text { 'survivorship':ab,ti }\end{array}$ & $\begin{array}{l}\# 7 \text { AND } \\
\# 8-254\end{array}$ \\
\hline Cochrane & $\begin{array}{l}\text { \#1 ("bone marrow transplantation"):ti,ab,kw OR } \\
\text { ("grafting, bone marrow"):ti,ab,kw OR ("bone marrow } \\
\text { grafting"):ti,ab,kw OR ("transplantation, bone } \\
\text { marrow"):ti,ab,kw OR ("bone marrow cell } \\
\text { transplantation"):ti,ab,kw OR } \\
\text { ("transplantation, bone marrow cell"):ti,ab,kw } \\
\text { \#2 ("hematopoietic stem cell transplantation"):ti,ab,kw OR } \\
\text { ("stem cell transplantation, hematopoietic"):ti,ab,kw OR } \\
\text { ("transplantation, hematopoietic stem cell"):ti,ab,kw } \\
\text { \#3 \#1 AND \#2 }\end{array}$ & $\begin{array}{l}\text { \#4 (“religion"):ti,ab,kw OR (“spiritual } \\
\text { therapy"):ti,ab,kw OR (“spiritual healing"):ti,ab,kw } \\
\text { OR(“"exorcism”):ti,ab,kw OR (“survivorship"):ti,ab,kw } \\
\text { \#5 (“spirituality"):ti,ab,kw OR } \\
\text { (“spiritualities"):ti,ab,kw OR (“spiritualism"):ti,ab,kw } \\
\text { \#6 \#4 OR \#5 }\end{array}$ & $\begin{array}{l}\# 3 \text { AND } \\
\# 6-13\end{array}$ \\
\hline
\end{tabular}

appraisal process. Please see Table 2 for MMAT scoring; a star represents an affirmative answer to a question. The reasons for scoring 4 stars are as follows: a high rate of attrition that leads to a high risk of nonresponse bias, ${ }^{17-19}$ small samples that may lack representativeness, ${ }^{20-22}$ and unclear data analysis methods. $^{23}$

\section{Inductive Analysis}

The inductive analysis of the 35 studies revealed the following three themes: the spiritual experiences of HSCT patients, the spiritual coping styles of HSCT patients, and the spiritual changes brought about by HSCT (Tables 4, 5, and 6).

Spiritual Experiences of HSCT Patients. The sample of this SMSR included respondents both with and without religious beliefs, but none of the original studies included in this SMSR separately described the spiritual experiences of patients without religious beliefs in detail. Feeling connected with God was the common spiritual experience of religious HSCT patients. ${ }^{1,24-28}$ This feeling was usually manifested in the aspects of a "positive view of disease" and "belief in God and destiny." After knowing that they were ill, most religious participants viewed the illness positively; some were willing to think that their "sickness is not seen as a misfortune," 25 and even that HSCT is a "divine test," 27 thereby affirming that "their life has a purpose." 28 Most of the religious participants were willing to believe in God, ${ }^{27,} 28$ although some patients thought that their illness was an atonement or a punishment for sins, which they accepted frankly. ${ }^{27}$ Quantitative evidence indicated that spiritual experiences in all sample groups were 


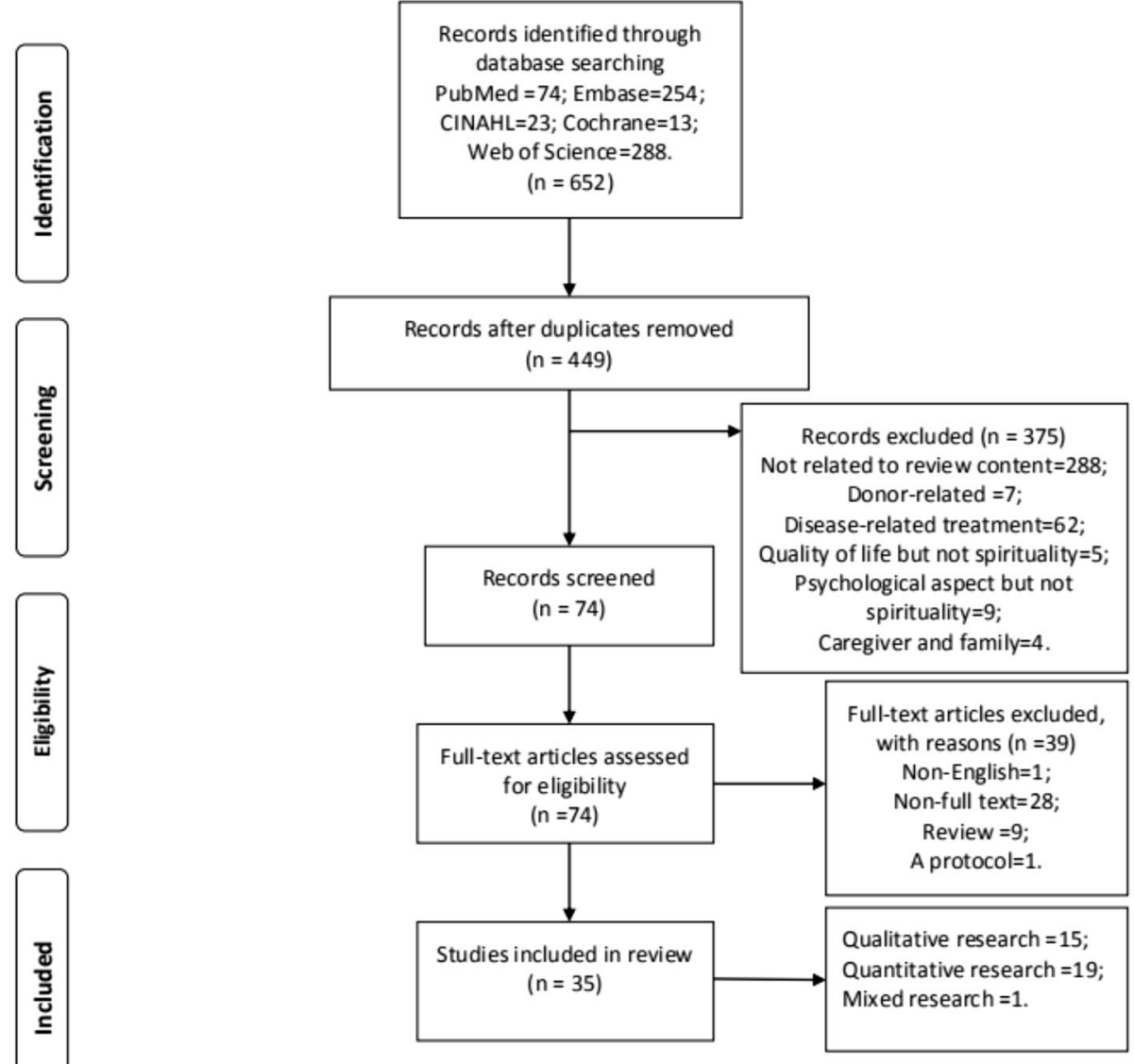

Figure 1 Flow diagram of individual studies screening.

affected by complications, ethnicity, education, culture, and income. ${ }^{17,22,29-31}$ Harris et al. ${ }^{21}$ and Prince et al. ${ }^{29}$ indicated that the QOL of patients with the lowest spirituality level is significantly different from those with higher spirituality levels. Pereira et al. ${ }^{32}$ proposed that patients with a spiritual absence and problematic compliance had greater hazards regarding 1-year all-cause mortality.

The participants included in this SMSR thought that the current system did not meet their spiritual needs. For example, the participants with religious beliefs thought that their spiritual experience during this difficult period needed the help of a psychotherapist. $^{33}$ In addition, when assessing QOL, both patients with religious beliefs and those with nonreligious beliefs tended to choose scales with spiritual items. ${ }^{34}$ Some religious participants felt that spiritual/religious struggle was due to perceived risk and limited time, ${ }^{23,26}$ which are significantly associated with gender, race, and time since diagnosis but not with QOL or medical variables. ${ }^{18,35}$

Spiritual Coping Styles of HSCT Patients. There are two forms of spiritual coping. External forms ${ }^{3,25,28,36,37}$ of spiritual coping for religious participants include "supplication," "reading from the Holy Book and listening to its Recitation," 25 and "receiving spiritual encouragement from family support or other survivors." 25,28 Internal forms
$1,3,25,28,33,38$ of spiritual coping for religious participants include patience, ${ }^{25}$ "acceptance of fate,"1 "reliance on faith," and a "genuine belief in God as the best cure for disease and sickness." 25

In contrast, external forms of spiritual coping for nonreligious participants include "seeking spiritual support from family members or friends" 36 and "finding meaning of life." 3 Internal forms of spiritual coping for nonreligious participants include "appreciating life" 3 and "self-purification." 33

Spiritual Need Changes Brought About by HSCT. Both participants with religious beliefs and those with nonreligious beliefs usually felt "spiritual dependence increases" after HSCT. 11,20,22,28,31,32,44,45 Religious participants had a greater reliance on religious and spiritual activities after $\mathrm{HSCT}^{42}$ such as "more committed to prayers than before; an increased faith in God helped me to feel stronger." 25 The studies included in this SMSR did not elaborate on these details for nonreligious participants. A quantitative study indicated that there was a significant negative association between spiritual growth and total perceived stress. ${ }^{39}$ Older participants reported more spiritual growth than younger participants. ${ }^{19}$ Religious faith and the meaning of peace dimension of spirituality improved after HSCT but not after allogeneic HSCT. ${ }^{8,17,19,29,40,41}$ It is 


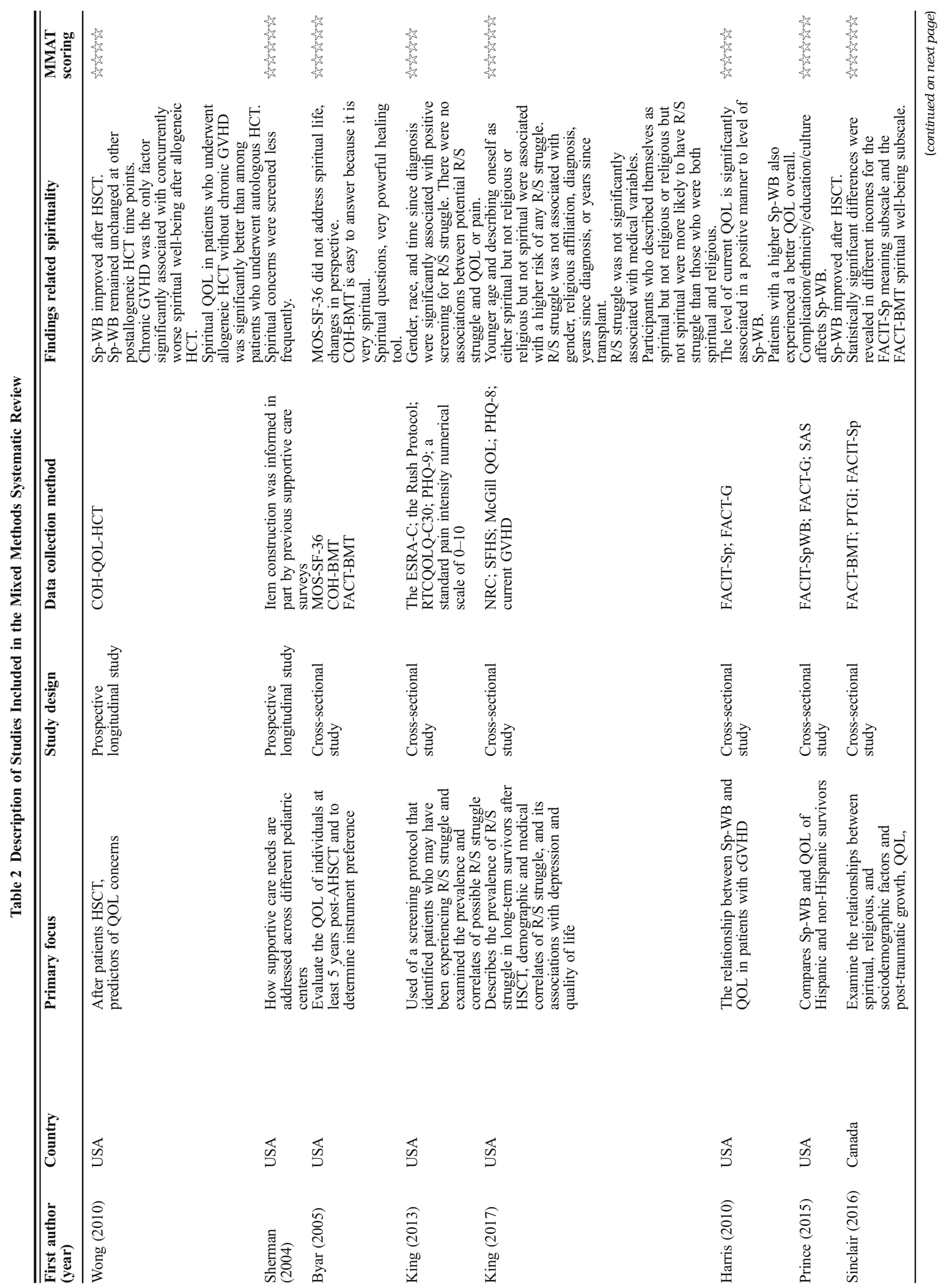




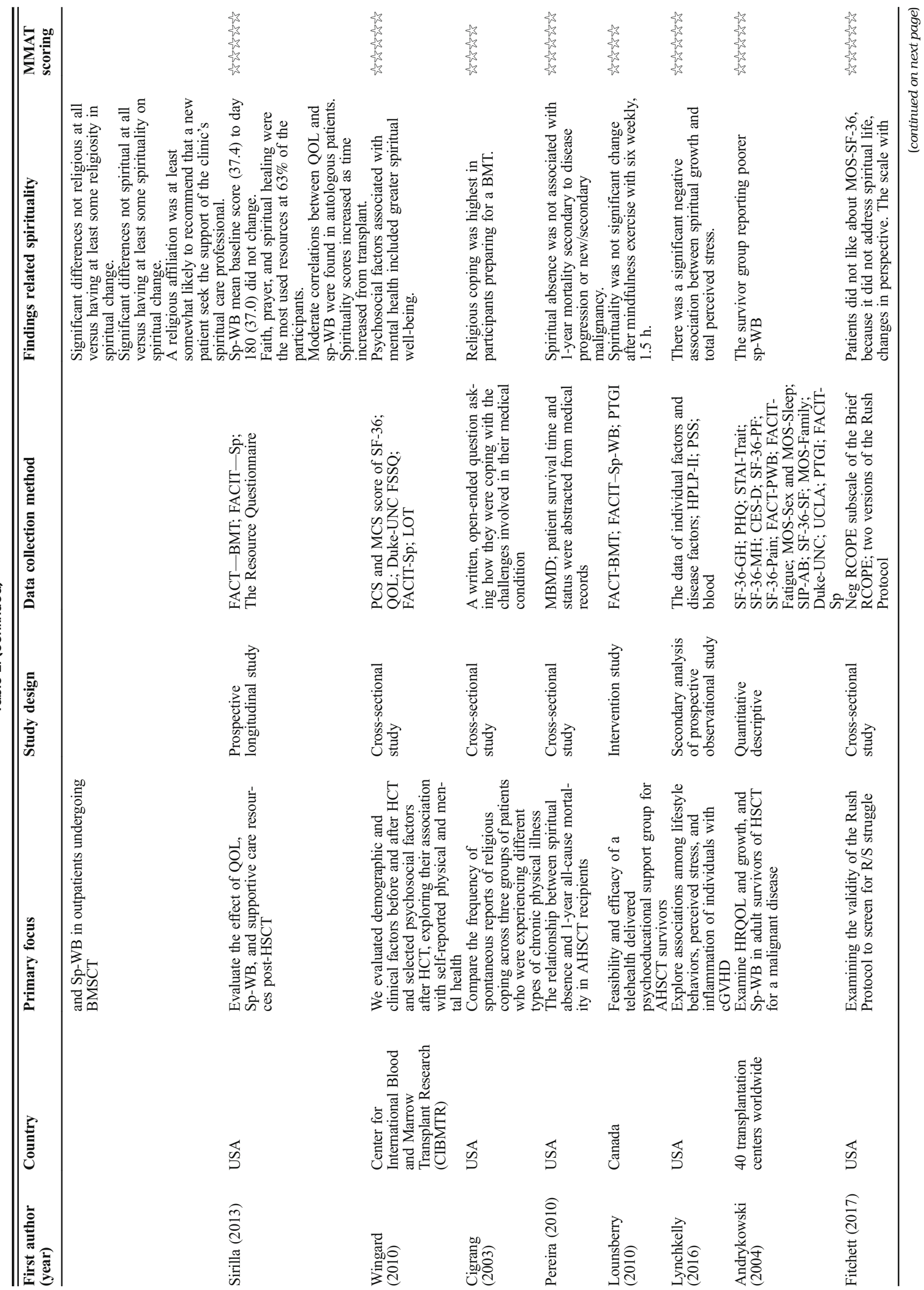




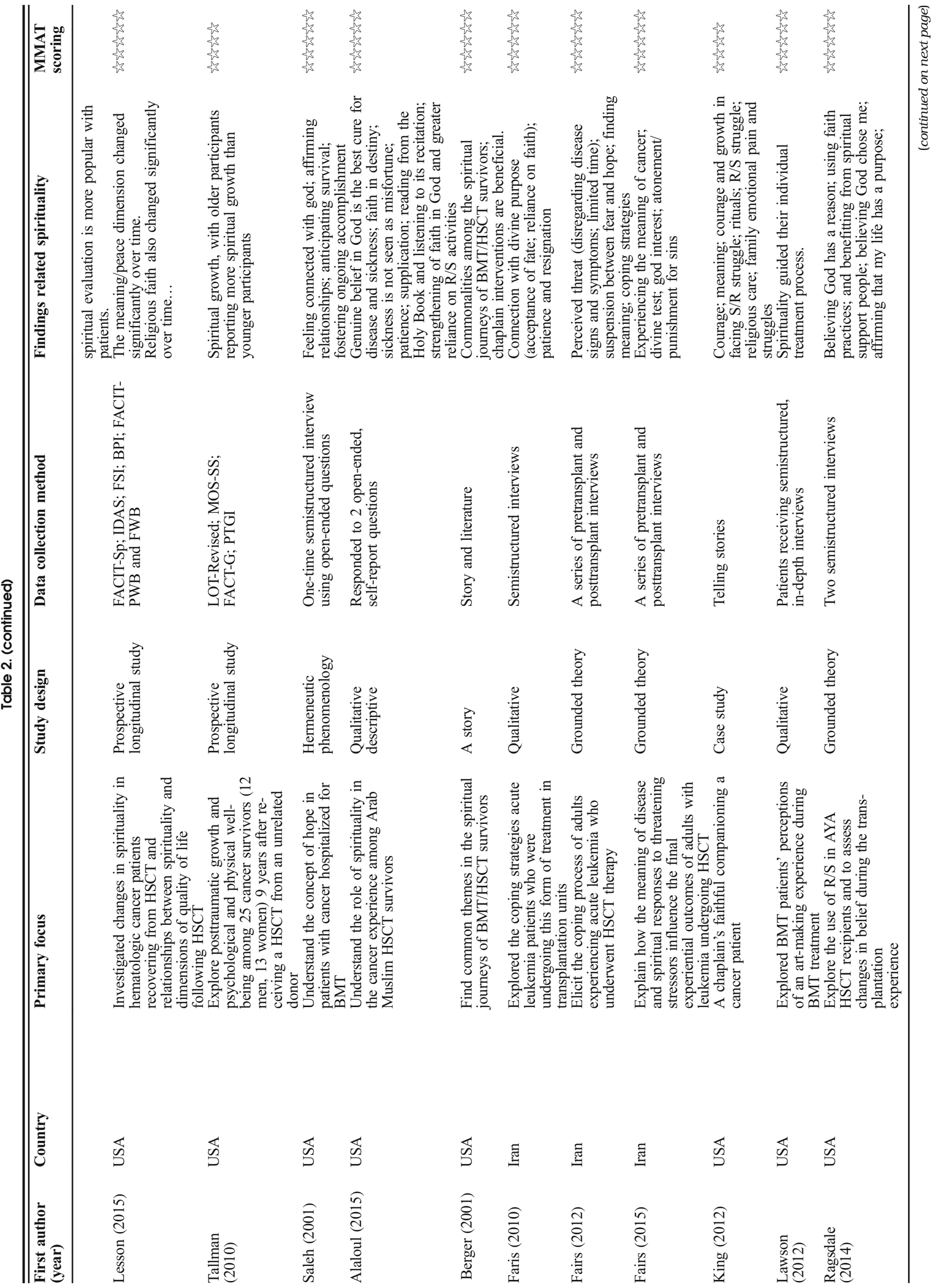




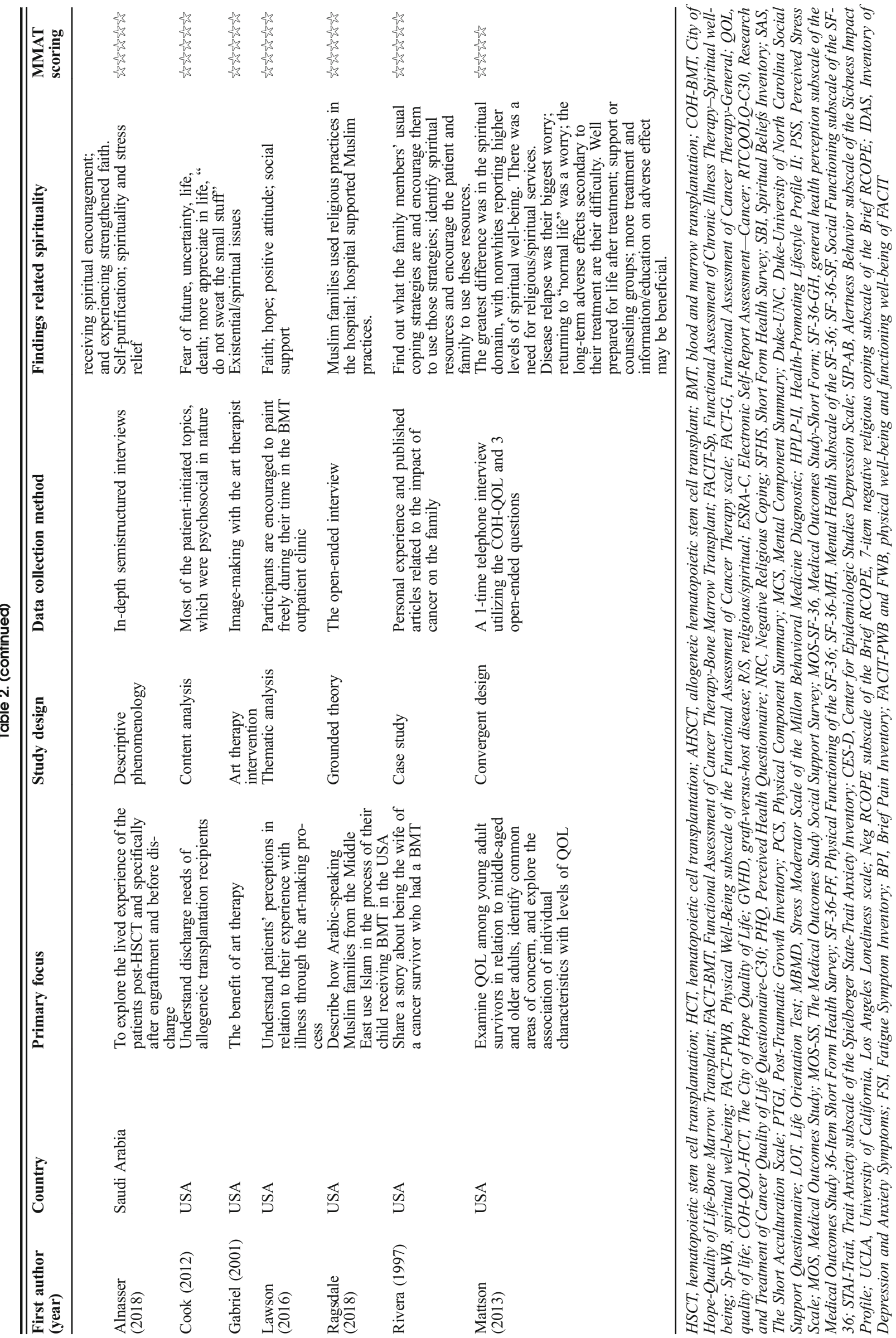




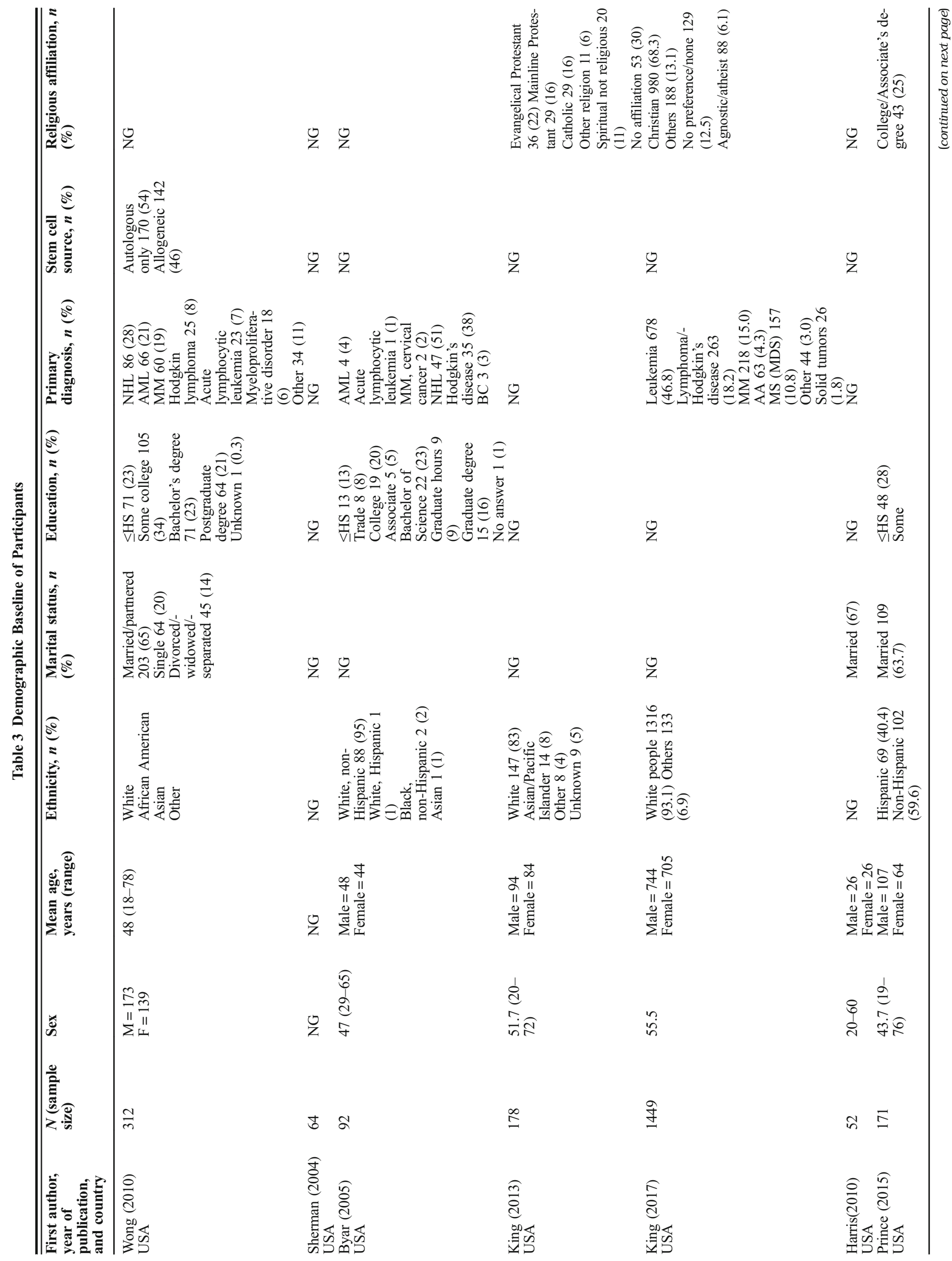




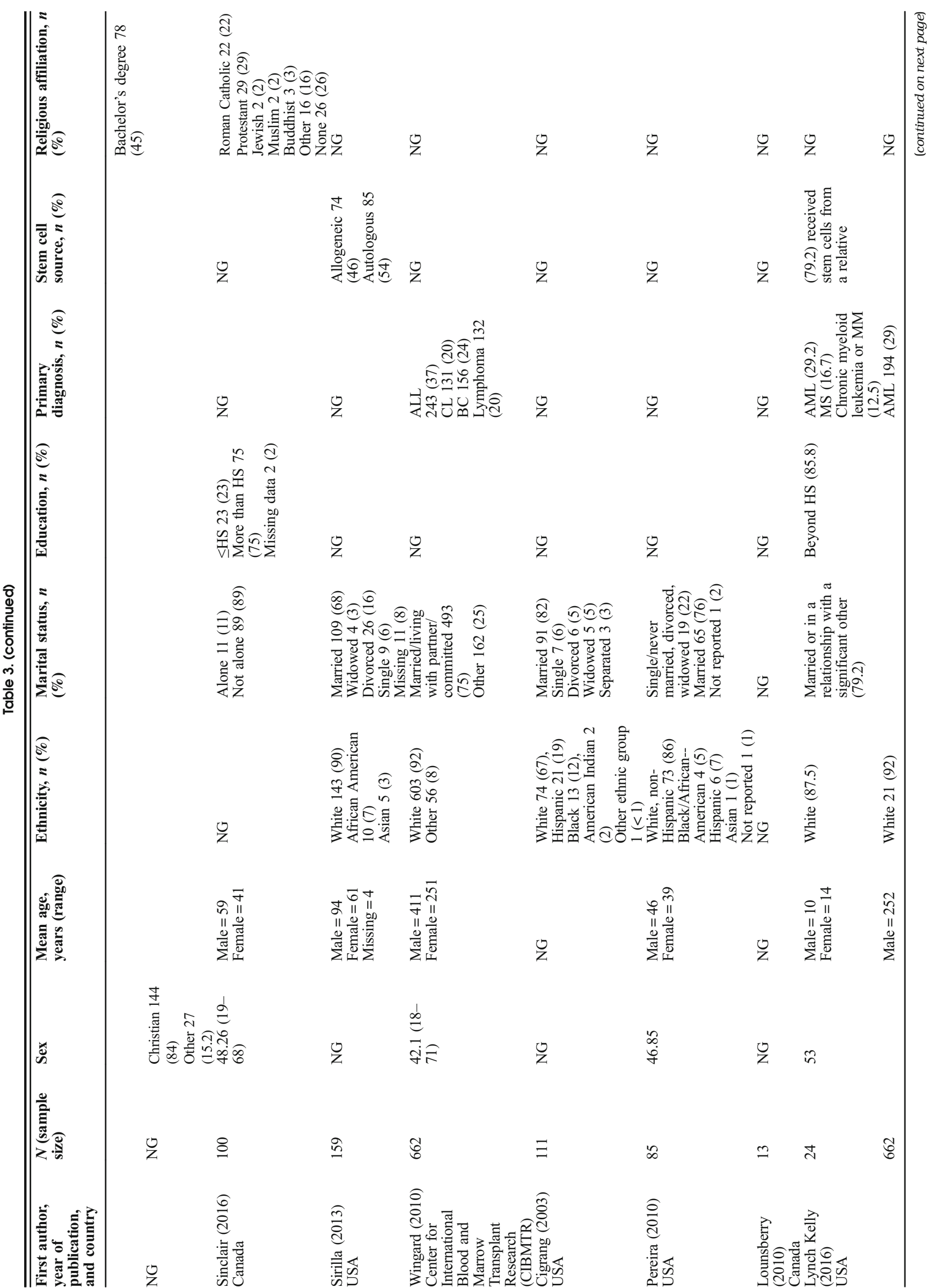




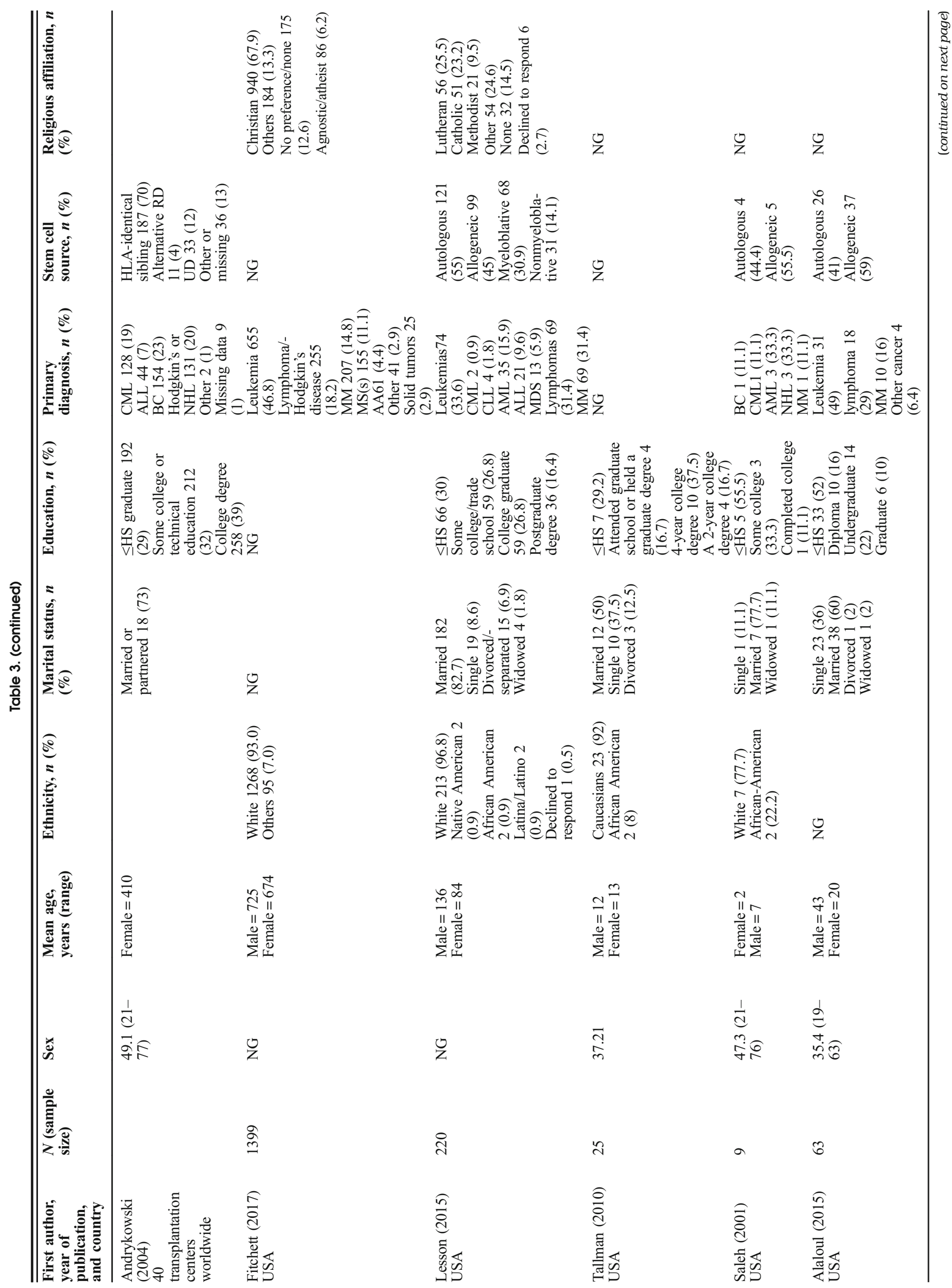




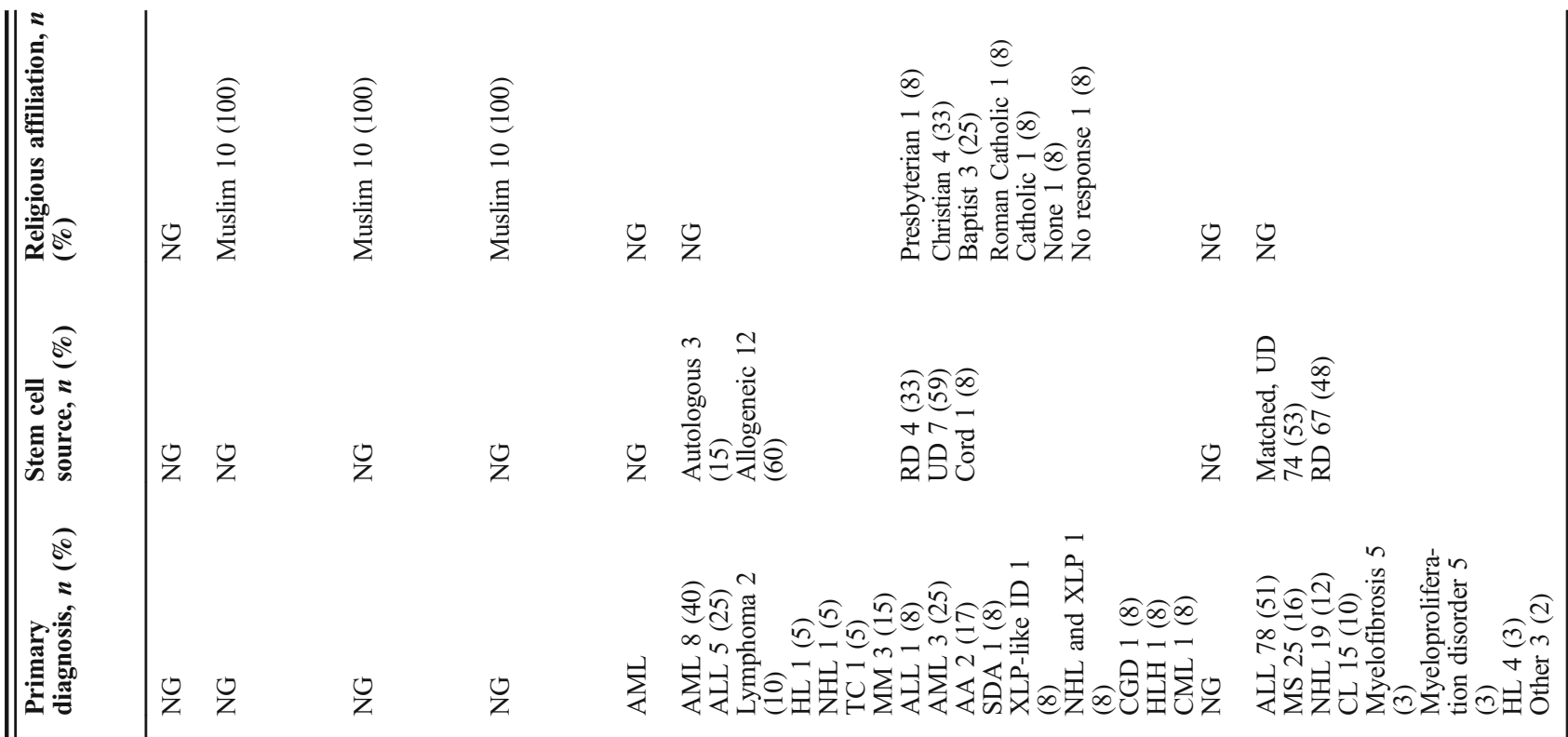

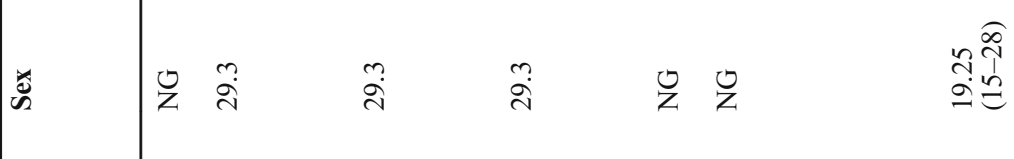

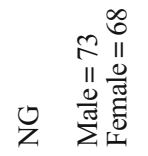

을

犊。

$-$ 인

$$
\text { 은 }
$$

은

$-8$

$\simeq$

ㅋ

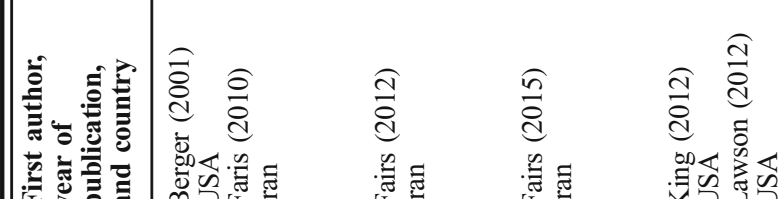




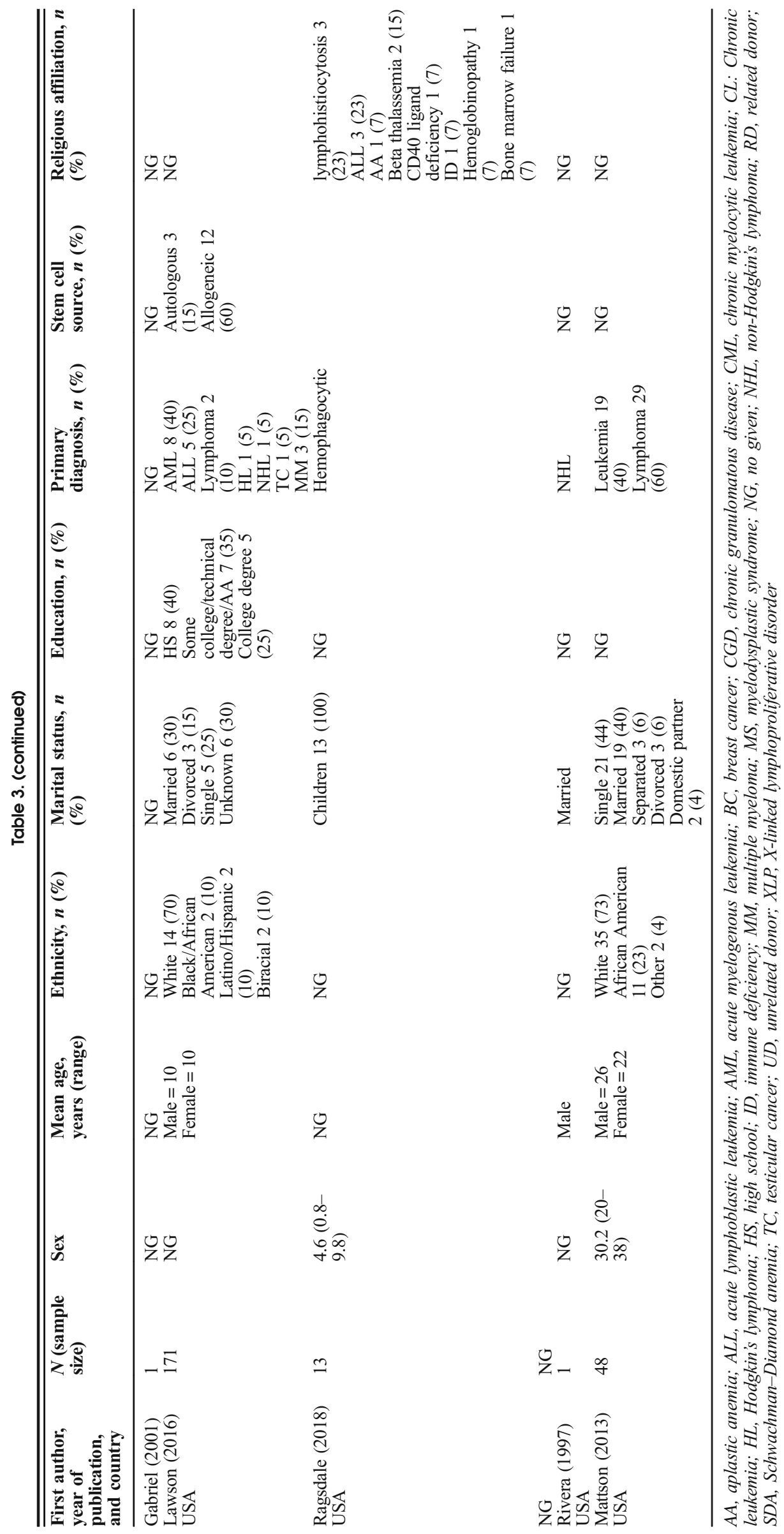


Table 4 Summary Table of Spiritual Experience

\begin{tabular}{|c|c|c|}
\hline $\begin{array}{l}\text { Spiritual } \\
\text { experience }\end{array}$ & Quantitative articles & Qualitative articles \\
\hline $\begin{array}{l}\text { Quantitative } \\
\text { articles: } \\
\text { 1. (Wong, } \\
\text { 2010) } \\
\text { 2. (Sherman, } \\
\text { 2004) } \\
\text { 3. (Byar, } \\
\text { 2005) } \\
\text { 4. (King, } \\
\text { 2013) } \\
\text { 5. (King, } \\
\text { 2017) } \\
\text { 6. (Harris, } \\
\text { 2010) } \\
\text { 7. (Prince, } \\
\text { 2015) } \\
\text { 8. (Sinclair, } \\
\text { 2016) } \\
\text { 9. (Sirilla, } \\
\text { 2013) } \\
\text { 10. (Wingard, } \\
\text { 2010) } \\
\text { 11. (Cigrang, } \\
\text { 2003) } \\
\text { 12. (Mattson, } \\
\text { 2013) } \\
\text { Qualitative } \\
\text { articles: } \\
\text { 13. (Saleh, } \\
\text { 2001) } \\
\text { 14. (Alaloul, } \\
\text { 2015) } \\
\text { 15. (Berger, } \\
\text { 2001) } \\
\text { 16. (Faris, } \\
\text { 2010) } \\
\text { 17. (Fairs, } \\
\text { 2012) } \\
\text { 18. (Fairs, } \\
\text { 2015) } \\
\text { 19. (King, } \\
\text { 2012) } \\
\text { 20. (Lawson, } \\
\text { 2012) } \\
\text { 21. (Ragsdale, } \\
\text { 2014) }\end{array}$ & $\begin{array}{l}\text { - Sp-WB is affected by } \\
\text { ethnicity/education/cul- } \\
\text { ture/incomes, but not } \\
\text { by stem cell source } \\
(1+7+8+11+12) \\
\text { - The scale with } \\
\text { spiritual assessment is } \\
\text { more popular than } \\
\text { nonspiritual assessment } \\
\text { with HSCT patients } \\
\text { because of its powerful } \\
\text { healing ability }(2+3) \\
\text { - Sp-WB is an } \\
\text { important part of } \\
\text { psychosocial factors } \\
\text { and the higher it is, } \\
\text { the better overall QOL } \\
\text { is }(1+6+9+10) \\
\text { - Sp-WB in allogeneic } \\
\text { HSCT patients without } \\
\text { chronic GVHD was } \\
\text { significantly better than } \\
\text { autologous HSCT } \\
\text { patients }(1) \\
\text { - The level of spiritual } \\
\text { well-being is worse } \\
\text { after patients who } \\
\text { underwent allogeneic } \\
\text { HSCT with chronic } \\
\text { GVHD (1) } \\
\text { - R/S struggle was } \\
\text { significantly associated } \\
\text { with gender, race, and } \\
\text { time since diagnosis, } \\
\text { but not with QOL and } \\
\text { medical variables } \\
(4+5)\end{array}$ & $\begin{array}{l}\text { - Feeling connected with } \\
\text { God }(13+14+15+16+ \\
17+18+19+20+21) \\
\text { - Spiritual/religious } \\
\text { struggle (19) }\end{array}$ \\
\hline
\end{tabular}

possible that there are more complications and symptom burdens related to allogeneic HSCT than to autologous HSCT.
Table 6 Summary Table of Spiritual Changes

\begin{tabular}{|c|c|c|}
\hline $\begin{array}{l}\text { Spiritual } \\
\text { changes }\end{array}$ & Quantitative articles & $\begin{array}{l}\text { Qualitative } \\
\text { articles }\end{array}$ \\
\hline $\begin{array}{l}\text { Quantitative } \\
\text { articles: } \\
\text { 1. (Wong, 2010) } \\
\text { 7. (Prince, 2015) } \\
\text { 9. (Sirilla, 2013) } \\
\text { 29. (Lounsberry, } \\
\text { 2010) } \\
\text { 30. (Lynchkelly, } \\
\text { 2016) } \\
\text { 31. } \\
\text { (Andrykowski, } \\
\text { 2004) } \\
\text { 32. (Fitchett, } \\
\text { 2017) } \\
\text { 33. (Lesson, } \\
\text { 2015) } \\
\text { 34. (Tallman, } \\
\text { 2010) } \\
\text { Qualitative } \\
\text { articles: } \\
\text { 14. (Alaloul, } \\
\text { 2015) } \\
\text { 21. (Ragsdale, } \\
\text { 2014) } \\
\text { 28. (Ragsdale, } \\
\text { 2018) } \\
\text { 35. (Rivera, } \\
\text { 1997) }\end{array}$ & $\begin{array}{l}\text { - There was a significant } \\
\text { negative association between } \\
\text { spiritual growth and total } \\
\text { perceived stress }(30) \\
\text { - Sp-WB mean baseline } \\
\text { score did not change for the } \\
\text { overall allogeneic and autol- } \\
\text { ogous group }(31+9) \\
\text { - Religious faith, } \\
\text { meaning/peace dimension of } \\
\text { spiritual improved after } \\
\text { autologous HSCT } \\
\text { ( } 1+7+9+32+33+34) \\
\text { - Older participants reporting } \\
\text { more spiritual growth than } \\
\text { younger participants }(34) \\
\text { - Spiritual was not } \\
\text { significantly changed after } \\
1.5 \text { h of mindfulness exercise } \\
\text { for } 6 \text { weeks }(29)\end{array}$ & $\begin{array}{l}\text { - Greater reliance } \\
\text { on religious/ } \\
\text { spiritual activities } \\
(14+28) \\
\text { - Strengthening of } \\
\text { faith in God } \\
(14+21+35)\end{array}$ \\
\hline
\end{tabular}

\section{DISCUSSION}

\section{Summary of Evidence}

This SMSR has integrated qualitative and quantitative evidence on the spiritual experiences of patients who underwent HSCT. In this SMSR, most participants ${ }^{1,25,27}$ were Muslims. Other participants ${ }^{28,42}$ had diverse religious beliefs, including Presbyterian, Christian, Baptist, Catholic, Roman Catholic, Catholic, Protestant, Mormon, others, and none. The following three themes were revealed: the spiritual experiences of HSCT patients, the spiritual coping styles of HSCT patients, and the spiritual need changes brought about by HSCT. The lack of spiritual support is a key issue in the spiritual experiences of HSCT patients, although they have different spiritual coping styles. Both participants with religious beliefs and

Table 5 Summary Table of Spiritual Coping Style of HSCT Patients

\begin{tabular}{|c|c|c|}
\hline $\begin{array}{l}\text { Spiritual coping } \\
\text { style }\end{array}$ & Quantitative articles & Qualitative articles \\
\hline $\begin{array}{l}\text { Quantitative articles: } \\
\text { 9. (Sirilla, 2013) } \\
\text { 22. (Hefner, 2017) } \\
\text { 23. (Pereira, 2010) } \\
\text { Qualitative articles: } \\
\text { 14. (Alaloul, 2015) } \\
\text { 17. (Faris, 2010) } \\
\text { 21. (Ragsdale, 2014) } \\
\text { 24. (Alnasser, 2018) } \\
\text { 25. (Cook, 2012) } \\
\text { 26.(Gabriel, 2001) } \\
\text { 27. (Lawson, 2016) } \\
\text { 28. (Ragsdale, 2018) } \\
\text { 12.(Mattson, 2013) }\end{array}$ & $\begin{array}{l}\text { - Religiousness and search for meaning showed to be the dominant coping } \\
\text { style, but it has nothing to do with sociodemographic variables }(22) \\
\text { - Spiritual absence has nothing to do with 1-year mortality secondary to } \\
\text { disease progression ( } 23 \text { ) } \\
\text { - Faith, prayer, and spiritual healing were the most used resources (9) }\end{array}$ & $\begin{array}{l}\text { - External form of spiritual coping } \\
(12+14+21+26+27+28) \\
\text { - Internal form of spiritual coping } \\
(14+17+21+24+25+26)\end{array}$ \\
\hline
\end{tabular}


those with nonreligious beliefs usually felt "spiritual dependence increases" after HSCT.

The integration results showed that HSCT patients need spiritual support regardless of whether the participants have various religious beliefs. The content and form of spirituality are different in participants with different religious beliefs. Religion has a great influence on Muslims' daily lives, especially during difficult times, which indicates the importance of incorporating religious needs into the nursing plans for Muslim patients and survivors. ${ }^{25}$ Ragsdale et al. ${ }^{28}$ have shown that faith participants can use their beliefs to "accept spiritual encouragement." Patients with higher levels of religious beliefs are more willing to accept medical intervention guidelines than are those with lower levels of religious beliefs. ${ }^{43}$ Previous studies ${ }^{7,12,13}$ have shown that religious and spiritual beliefs contribute to cancer adaptation. These findings are consistent with the integrated results of this study.

The spiritual support of patients without religious beliefs comes from the company of family, friends, or nurses. According to Liang et al., ${ }^{44}$ families can satisfy the spiritual needs of patients by accompanying the patients. These patients share an appreciation for the people who bolster their faith. Therefore, support from patients or nurses with the same beliefs should be involved in the healthcare systems. Consequently, meeting and understanding the spiritual needs of patients and families in the healthcare systems will provide better care and higher satisfaction levels for HSCT patients. Alnasser et al. indicated that patients seek help from family members to meet their spiritual needs because hospitals do not provide such services. ${ }^{33}$ Therefore, professional spiritual services should be provided in the care plan of every HSCT patient. We suggest that priests with clinical education backgrounds as psychotherapists should be involved in the field of health care in the future. These priests can be instructed to provide suitable spiritual-based interventions for patients, which would contribute to improving the quality of life of HSCT patients.

\section{Strengths and Limitations of the Review}

To the best of our knowledge, this is the first systematic mixed studies review to integrate and assess evidence on the spiritual needs of patients undergoing HSCT. Although the search strategy was thorough, it may have missed sources in the gray literature. The included studies were conducted in countries with strong religious beliefs (Canada, Iran, Saudi Arabia, the USA), which means that the current study results may be quite different from the results of other countries. Thus, the current results are not enough to show the full picture of the role of spirituality in the experience of HSCT. Different researchers may have different integration themes due to the subjective determination of researchers. To reduce the risk of data bias in the current study, two main researchers (L.Y.Z. and X.Y.Z.) from our research group summarized similar topics and identified a more appropriate topic through discussion when they had differences.

\section{CONCLUSION}

It is certain that all patients need spiritual support during an illness. HSCT patients with different cultural backgrounds may have different spiritual experiences and spiritual coping styles. However, few medical institutions currently offer spiritual healing. Nurse psychotherapists or professional priests should be considered to provide spiritual care for patients undergoing HSCT, to help patients cope with disease pressures, promote their comfort, and improve their quality of life.

Corresponding Author: Xiu-ying Zhang, PhD; Department of Fundamental Nursing, School of Nursing Jilin University, Changchun 130021, Jilin, People's Republic of China (e-mail: $\left.z \_x y @ j l u . e d u . c n\right)$.

Funding Information This work was supported by funds of the Undergraduates' Teaching Reform Project of Jilin University [2017XYB121] and the Education Department of Jilin Province [JJKH20170843KJ and JJKH20180293SK].

\section{Compliance with Ethical Standards:}

Conflict of Interest: The authors declare that they do not have a conflict of interest.

\section{REFERENCES}

1. Farsi Z, Dehghan Nayeri N, Negarandeh $\mathbf{R}$. Coping strategies of adults with leukemia undergoing hematopoietic stem cell transplantation in Iran: a qualitative study. Nursing \& health sciences. 2010;12(4):485-492.

2. Cooke L, Gemmill R, Kravits $\mathbf{K}$, et al. Psychological issues of stem cell transplant. Seminars in Oncolology Nursing. 2009;25(2):139-150.

3. Cooke L, Grant M, Gemmill R. Discharge needs of allogeneic transplantation recipients. Clinical Journal of Oncology Nursing. 2012;16(4):E142149.

4. Frick E, Fegg MJ, Tyroller M, et al. Patients' health beliefs and coping prior to autologous peripheral stem cell transplantation. European Journal of Cancer Care. 2010;16(2):156-163.

5. Miedema B, Hamilton R, Easley J. From "invincibility" to "normalcy": Coping strategies of young adults during the cancer journey. Palliat Support Care. 2007;5:41-49.

6. Grulke N, Bailer H, Hertenstein B, et al. Coping and survival in patients with leukemia undergoing allogeneic bone marrow transplantation-longterm follow-up of a prospective study. J Psychosomatic Res. 2005;59(5):337-346.

7. Schulz E, Holt C, Caplan L, et al. Role of spirituality in cancer coping among African Americans: A qualitative examination. Journal of Cancer Survivorship. 2008;2(2): 104-115.

8. Sirilla J, Overcash J. Quality of life (QOL), supportive care, and spirituality in hematopoietic stem cell transplant (HSCT) patients. Supportive Care in Cancer. 2013;21(4):1137-1144.

9. van Leeuwen R, Schep-Akkerman A, van Laarhoven HW. Screening patient spirituality and spiritual needs in oncology nursing. Holist Nurs Pract. 2013;27(4):207-216.

10. Visser A, Garssen B, Vingerhoets A. Spirituality and well-being in cancer patients: a review. Psycho-oncology. 2010;19(6):565-572.

11. JA S, DY B. Twenty-five years later-what do we know about religion/ spirituality and psychological well-being among breast cancer survivors? A systematic review. J Cancer Surviv. 2012;6(1):82-94.

12. Delgado-Guay MO, Hui D, Parsons HA, et al. Spirituality, religiosity, and spiritual pain in advanced cancer patients. Journal of Pain and Symptom Management. 2011;41(6):986-994.

13. Vallurupalli M, Lauderdale $\mathbf{K}$, Balboni MJ, et al. The role of spirituality and religious coping in the quality of life of patients with advanced cancer receiving palliative radiation therapy. The Journal of Supportive Oncology. $2012 ; 10(2): 81-87$. 
14. Pluye $\mathbf{P}$, Hong $\mathbf{Q N}$. Combining the power of stories and the power of numbers: mixed methods research and mixed studies reviews. Annu Rev Public Health. 2014;35:29-45.

15. Moher D, Liberati A, Tetzlaff $\mathbf{J}$, et al. Preferred reporting items for systematic reviews and meta-analyses: the PRISMA statement. PLoS Med. 2009;6(7)

16. Thomas J, Harden A. Methods for the thematic synthesis of qualitative research in systematic reviews. BMC Med Res Methodol 2008;8(1):45-45.

17. Wong FL, Francisco $\mathbf{L}$, Togawa $\mathbf{K}$, et al. Long-term recovery after hematopoietic cell transplantation: predictors of quality-of-life concerns. Blood. 2010;115(12):2508-2519.

18. King SD, Fitchett G, Berry DL. Screening for religious/spiritual struggle in blood and marrow transplant patients. Supportive Care in Cancer: official journal of the Multinational Association of Supportive Care in Cancer. 2013;21(4):993-1001

19. Tallman B, Shaw K, Schultz J, et al. well-being and posttraumatic growth in unrelated donor marrow transplant survivors: A nine-year longitudinal study. Rehabilitation Psychology. 2010;55(2):204-210.

20. Lounsberry JJ, MacRae H, Angen M, et al. Feasibility study of a telehealth delivered, psychoeducational support group for allogeneic hematopoietic stem cell transplant patients. Psycho-oncology. 2010;19(7):777-781.

21. Harris BA, Berger AM, Mitchell SA, et al. Spiritual well-being in longterm survivors with chronic graft-versus-host disease after hematopoietic stem cell transplantation. The Journal of Supportive Oncology. 2010;8(3):119-125.

22. Cigrang JA, Hryshko-Mullen A, Peterson AL. Spontaneous reports of religious coping by patients with chronic physical illness. Journal of Clinical Psychology in Medical Settings. 2003;10(3):133-137.

23. King SDW. Facing Fears and Counting Blessings: A Case Study of a Chaplain's Faithful Companioning a Cancer Patient. Journal of Health Care Chaplaincy. 2012;18(1/2):3-22.

24. Saleh US, Brockopp DY. Hope among patients with cancer hospitalized for bone marrow transplantation-A phenomenologic study. Cancer Nursing. 2001;24(4):308-314.

25. Alaloul F, Schreiber JA, Al Nusairat TS, et al. Spirituality in Arab Muslim hematopoietic stem cell transplantation survivors: A qualitative approach. Cancer Nursing. 2016;39(5):E39-E47.

26. Farsi Z, Nayeri ND, Negarandeh $\mathbf{R}$. The Coping Process in Adults With Acute Leukemia Undergoing Hematopoietic Stem Cell Transplantation. Journal of Nursing Research. 2012;20(2):99-109.

27. Farsi Z. The Meaning of Disease and Spiritual Responses to Stressors in Adults With Acute Leukemia Undergoing Hematopoietic Stem Cell Transplantation. J Nurs Res. 2015;23(4):290-297.

28. Ragsdale JR, Hegner MA, Mueller M, et al. Identifying religious and/or spiritual perspectives of adolescents and young adults receiving blood and marrow transplants: a prospective qualitative study. Biology of Blood and Marrow Transplantation : journal of the American Society for Blood and Marrow Transplantation. 2014;20(8): 1242-1247.

29. Prince P, Mitchell SA, Wehrlen $\mathbf{L}$, et al. Spiritual Well-Being in Hispanic and Non-Hispanic Survivors of Allogeneic Hematopoietic Stem Cell Transplantation. Journal of Psychosocial Oncology. 2015;33(6):635-654.

30. Sinclair S, Booker R, Fung T, et al. Factors Associated With PostTraumatic Growth, Quality of Life, and Spiritual Well-Being in
Outpatients Undergoing Bone Marrow Transplantation: A Pilot Study. Oncology Nursing Forum. 2016;43(6):772-780

31. Mattson MR, Demshar RK, Daly BJ. Quality of Life of Young Adult Survivors of Hematologic Malignancies. Cancer Nursing. 2013;36(2):E1E7.

32. Pereira DB, Christian LM, Patidar S, et al. Spiritual absence and 1-year mortality after hematopoietic stem cell transplant. Biology of Blood and Marrow Transplantation : journal of the American Society for Blood and Marrow Transplantation. 2010;16(8):1171-1179.

33. Alnasser Q, Abu Kharmah SD, Attia M, et al. The lived experience of autologous stem cell-transplanted patients: Post-transplantation and before discharge. Journal of Clinical Nursing. 2018;27(7-8):e1508-e1518.

34. Byar KL, Eilers JE, Nuss SL. Quality of life 5 or more years postautologous hematopoietic stem cell transplant. Cancer Nurs. 2005;28(2):148-157.

35. King SD, Fitchett G, Murphy PE, et al. Spiritual or religious struggle in hematopoietic cell transplant survivors. Psycho-oncology. 2017;26(2):270-277

36. Lawson LM, Chau J, Schoel A. Thematic analysis of tiles painted by blood and marrow transplant patients during treatment. European Journal of Cancer Care. 2016;25(6):1044-1055.

37. Ragsdale JR, Othman M, Khoury R, et al. Islam, The Holy Qur'an, and Medical Decision-Making: The Experience of Middle Eastern Muslim Families with Children Undergoing Bone Marrow Transplantation in the United States. The Journal of Pastoral Care \& Counseling: JPCC. 2018;72(3):180-189.

38. Gabriel B, Bromberg E, Vandenbovenkamp J, et al. Art therapy with adult bone marrow transplant patients in isolation: a pilot study. Psychooncology. 2001;10(2):114-123.

39. Lynch Kelly D, Lyon DE, Periera D, et al. Lifestyle Behaviors, Perceived Stress, and Inflammation of Individuals With Chronic Graft-Versus-Host Disease. Cancer Nurs. 2018;41(1):11-22.

40. Fitchett G, Murphy P, King SDW. Examining the Validity of the Rush Protocol to Screen for Religious/Spiritual Struggle. J Health Care Chaplain. 2017;23(3):98-112.

41. Leeson LA, Nelson AM, Rathouz PJ, et al. Spirituality and the recovery of quality of life following hematopoietic stem cell transplantation. Health Psychology. 2015;34(9):920-928.

42. Cooke L, Chung C, Grant M. Psychosocial Care for Adolescent and Young Adult Hematopoietic Cell Transplant Patients. Journal of Psychosocial Oncology. 2011;29(4):394-414.

43. Balboni TA, Balboni MJ, Enzinger AC, et al. Provision of spiritual support to patients with advanced cancer by religious communities and associations with medical care at the end of life. JAMA Internal Medicine. 2013;173(12): 1-9

44. Liang $\mathbf{T}$, Lin $\mathbf{K}$, Yeh $\mathbf{S}$, et al. Lived experience of patients undergoing allogeneic peripheral hematopoietic stem cell transplant. International Journal of Research in Medical and Health Science 2014;4(2):36-46.

Publisher's Note Springer Nature remains neutral with regard to jurisdictional claims in published maps and institutional affiliations. 